\title{
By-product feeds as sources of fiber for lactating cows fed low forage diets ${ }^{1}$
}

\author{
Teodoro M. Ruiz $z^{2}$ and Jaime Moyá ${ }^{3}$ \\ J. Agric. Univ. P.R. 90(1-2):27-36 (2006) \\ ABSTRACT
}

\begin{abstract}
The effectiveness of the fiber in whole cottonseed (WCS), wheat midds (WM), and rice bran was evaluated in Holstein cows in early lactation (30 to 50 days) fed mixed rations, low in neutral detergent fiber (NDF) concentration. Treatments evaluated were: (T1) control, a diet formulated to $25 \%$ NDF with 19\% NDF from chopped hay (NDFH); (T2) a diet formulated to $35 \%$ NDF containing $19 \%$ NDFH with the additional $10 \%$ NDF provided by a mixture of the three by-product feeds in the concentrate; and (T3) a diet formulated to $25 \%$ NDF with $10 \%$ NDFH and the remainder provided in the concentrate from by-product feeds. All cows were fed $6 \%$ of the total DM as alfalfa hay and pangola grass hay to meet NDFH targets. Treatment differences in DM intake $(18.3 \mathrm{~kg} / \mathrm{d})$, DM intake as a percentage of body weight $(3.22 \%)$, milk production $(32.7 \mathrm{~kg} / \mathrm{d})$, and milk protein concentration $(2.65 \%)$ were not significant $(P>0.05)$. Reducing the NDFH to $10 \%$ resulted in a $15 \%(P<0.01)$ relative reduction in milk fat concentration that was not prevented by restoring the NDF level with the mixture of WCS, WM, and rice bran. Despite the fact that cows consumed more energy for milk production $\left(\mathrm{NE}_{\mathrm{L}}\right)$ from $\mathrm{T} 3$, the energetic efficiency of milk production (Mcal-milk/Mcal-feed) was about $15 \%$ higher $(P<0.01)$ when the cows consumed $19 \%$ NDFH (T1 and T2). Fiber from by-product feeds was ineffective in maintaining milk fat concentration above $3.0 \%$ and did not result in improvement in milk production or efficiency of milk production. Thus, the NDF in the mixture of by-product feeds had no ruminally effective fiber value under the conditions of this experiment.
\end{abstract}

Key words: NDF, dairy cows, nonforage fiber

\section{RESUMEN}

\section{Subproductos vegetales como fuente de fibra para vacas lactantes consumiendo dietas bajas en forraje}

Se evaluó la efectividad de la fibra en la semilla de algodón entera (SA), salvado de trigo (ST) y la cascarilla de arroz en vacas Holstein en lactancia temprana ( 30 a 50 días) recibiendo dietas mezcladas bajas en fibra detergente neutra (FDN). Los tratamientos experimentales evaluados fueron (T1) control, dieta formulada para $25 \%$ FDN con $19 \%$ FDN provisto por heno picado (FDNH); (T2) dieta formulada para 35\% FDN con $19 \%$ FDNH y el exceso de FDN provisto por la mezcla de SA, AT, y cascarilla de arroz en el concentrado; (T3) dieta formulada para $25 \%$ FDN con $10 \%$ FDNH y el remanente provisto por la mezcla de los tres subproductos en el concentrado. Todas las

${ }^{1}$ Manuscript submitted to Editorial Board 1 February 2005.

${ }^{2}$ Associate Researcher, Animal Industry Department, College of Agricultural Sciences, Univ. of Puerto Rico-Mayagüez, P.O. Box 9030, Mayagüez, PR 00681-9030.

${ }^{3}$ Former Assistant Researcher, Animal Industry Department. 


\begin{abstract}
vacas se alimentaron con heno de alfalfa al $6 \%$ del consumo total de MS y con heno de yerba pangola hasta alcanzar el FDNH deseado. Las diferencias entre los tratamientos no fueron estadísticamente significativas $(P>0.05)$ para consumo de MS $(18.3 \mathrm{~kg} / \mathrm{d})$, consumo a base de peso vivo $(3.22 \%)$, producción de leche $(32.7 \mathrm{~kg} / \mathrm{d})$ y concentración de proteína láctea $(2.65 \%)$. EI reducir la concentración de FDNH a 10\% (T3) resultó en una reducción relativa en la concentración de grasa láctea de un $15 \%(P<0.01)$ comparado a la alimentación con 19\% FDNH (T1 y T2). Aún cuando la dieta T3 resultó en un mayor consumo de energía para la producción de leche $\left(\mathrm{NE}_{\mathrm{L}}\right)$, la eficiencia energética en la producción de leche (Mcal-leche/Mcal-alimento) resultó aproximadamente $15 \%$ menor que al consumir las dietas con $19 \%$ FDNH (T1 yT2). La fibra adicional en la mezcla de subproductos en el concentrado (T2) no fue efectiva en promover o en aumentar la grasa láctea y tampoco pudo evitar una reducción en la grasa por debajo de $3.0 \%$ cuando se redujo la FDNH (T3). Por consiguiente, la FDN en la mezcla de subproductos no demostró ser de efectividad ruminal bajo las condiciones de este experimento.
\end{abstract}

Palabras clave: FDN, vacas lecheras, fibra

\title{
INTRODUCTION
}

Diets fed to dairy cows in some regions of the Caribbean tropics, such as Puerto Rico, are characterized by being rich in nonstructural carbohydrates and low in forage fiber (Ruiz et al., 2001). Feeding this type of diet will lead to a reduction in ruminal $\mathrm{pH}$ and impaired ruminal fermentation, conducive to lower acetate to propionate ratio (Varga et al., 1998). This condition will result in low concentration of fat in milk. A common strategy to compensate for the insufficiency of effective forage fiber in the diet is to include high-fiber feeds in the concentrate mix. Feeds such as wheat middlings, whole cottonseed and rice bran are preferred for their availability and competitive cost in the Caribbean region.

The effectiveness of nonforage high-fiber feeds in maintaining milk and fat production in cows consuming low forage diets has not been clearly established. Because of their smaller particle size and faster rate of passage, the filling effect of these high-fiber feeds in the rumen has been estimated to be about $30 \%$ of that of long fiber (Varga et al., 1998). Clark and Armentano (1993) studied the effectiveness of fiber from whole cottonseed and distillers' grains in comparison with that of alfalfa haylage in diets with $25 \%$ of neutral detergent fiber (NDF). These sources were found equal to alfalfa haylage in sustaining milk yield and milk fat concentration when they provided 4.0 and $5.7 \%$ of the dietary NDF, respectively. In another study, Harmison et al. (1997) substituted soybean hulls for a large portion of the NDF in diets containing 16 and $11 \%$ NDF from alfalfa silage, without any adverse effects on dry matter intake (DMI) or milk fat percentage in diets containing over $35 \% \mathrm{NDF}$.

Staples et al. (1995) studied the effect of adding dried distillers' grains in place of corn in diets of lactating dairy cows consuming corn silage-based diets. For diets marginal in NDF (21 to $28 \%$ NDF), the ad- 
dition of distillers' grains resulted in an increase in milk fat. However, this effect was reduced drastically as NDF concentration increased and was negative when the diet NDF was $34.5 \%$. On average, distillers' grains were found to be about $50 \%$ as effective as corn silage in supporting milk fat production. More recent research indicates that the forage fiber substituting potential of feeds such as distillers' grains, wheat middlings, and whole cottonseed is reduced when a mixture of these is included in the concentrate rather than when they are fed alone (Clark and Armentano, 1997). Understanding these relationships is essential to improving the quality of lactating cow diets and preventing milk fat decrease in cows consuming low forage diets and for this reason the present study was undertaken.

\section{MATERIALS AND METHODS}

Twelve Holstein cows in early lactation of the Gurabo Experiment Station herd, 30 to 50 days in milk at the start of the trial, were used in order to evaluate three dietary treatments. All cows were fed a concentrate feed based on corn and soybean meal; concentration of NDF in the concentrate was altered by substituting wheat middlings, whole cottonseed (WCS), and rice bran for corn and soybean meal. The diets evaluated were T1) control, $25 \%$ NDF with approximately $20 \%$ NDF from forage hay (NDFH); T2) 35\% NDF, 20\% NDFH and 15\% NDF from nonforage feeds; and T3) 25\% NDF with 10\% NDFH and 15\% NDF from nonforage feeds. Experimental cows were assigned to treatments according to a $3 \times$ 3 Latin Square Design, replicated four times. Each of the three periods was 21 days, the first 14 for adaptation to treatments and the last seven for data collection. To all cows, alfalfa hay was fed at $6 \%$ of the diet DM. The remainder of the NDFH was provided by 55-day-old pangola grass hay (PGH). The pangola grass and alfalfa hays were chopped to a length of about 6 to $9 \mathrm{~cm}$ and mixed with the concentrate prior to feeding it to the experimental cows. Mixed rations were fed ad libitum allowing approximately $10 \%$ orts daily. Cows were milked twice daily at 4:00 and 15:30 h, and were housed in an open sided barn provided with Calan gates to measure individual feed intake. After the afternoon milking, cows were allowed access to a dirt lot next to the barn. At each milking, milk production was measured by using calibrated (DHIA) milk meters. Milk samples to determine milk composition were collected during four consecutive milkings after day 19 of each experimental period.

Two samples of alfalfa hay, pangola grass hay, and of each of the concentrates were collected on a weekly basis throughout the experiment to determine DM and ingredient composition of the ration on an as-fed basis. A composite sample per period, of each feed, was dried in 
an air draft oven at $65^{\circ} \mathrm{C}$ for 48 hours. Dried samples were ground with a Wiley mill through a 2-mm screen and saved for further analyses. Each sample was analyzed for crude protein (CP), acid detergent fiber (ADF), NDF, $\mathrm{Ca}, \mathrm{P}, \mathrm{K}, \mathrm{Na}, \mathrm{Mg}$, and $\mathrm{Cl}$ (Dairy One Laboratory, Ithaca, NY) ${ }^{4}$ Ash content of the samples was determined by incineration in a Muffle furnace at $600^{\circ} \mathrm{C}$ for six hours.

A nonlactating fistulated Holstein cow was used to estimate the effect of dietary treatments on rumen $\mathrm{pH}$. The cow was fed a control ration (60\% grass hay) beginning seven days prior to sampling; beginning on day three a treatment ration progressively replaced $25 \%$ of the control ration daily until on day six the cow consumed $100 \%$ of the treatment ration. At sampling on day seven the cow was fed at 6:30 h half of the daily allowance; $\mathrm{pH}$ was measured with a Corning $\mathrm{pH}$ Meter (Model 445) in rumen fluid taken from two locations within the rumen, hourly for nine hours. The cow was fed again at 16:00. On the day of sampling, during each of the three sampling periods, the cow was fed $17 \mathrm{~kg} / \mathrm{d}$ of $\mathrm{DM}$ of the experimental rations in the following order: T1, T3, and T2.

The efficiency of feed conversion to milk and body weight (Mcal/ Mcal) was calculated on the basis of estimates of energy for milk production $\left(\mathrm{NE}_{\mathrm{L}}\right.$ ) from chemical composition (Dairy One Lab., Ithaca, NY). Energy content of milk production and body weight gain were estimated on the basis of equations provided by NRC (1989).

Data generated were analyzed by using the GLM procedure of SAS (Littell et al., 1991). Orthogonal contrasts were used to determine differences among treatment means.

\section{RESULTS AND DISCUSSION}

Ingredient composition of the concentrate mixes and rations is presented in Table 1. Ration composition was similar for $\mathrm{T} 1$ and $\mathrm{T} 2$; however, the concentration of $\mathrm{PGH}$ in the ration was lower, and that of concentrate higher, in T3 than in the other two dietary treatments.

The chemical composition of the concentrate mixes and of the alfalfa and pangola grass hays is presented in Table 2. Crude protein concentration was lowest in the concentrate mix used in T3, primarily because of its higher ratio of corn to soybean meal than in the other two concentrates. The estimated $\mathrm{NE}_{\mathrm{L}}$ content of the concentrate mixes decreased as their NDF concentration increased. Thus, the estimated $\mathrm{NE}_{\mathrm{L}}$ con-

\footnotetext{
${ }^{4}$ Trade names in this publication are used only to provide specific information. Mention of a trade name does not constitute a warranty of equipment or materials by the $\mathrm{Ag}$ ricultural Experiment Station of the University of Puerto Rico, nor is this mention a statement of preference over other equipment or materials.
} 
TABLE 1. Ingredient composition of experimental diets and of concentrates used to feed cows consuming diets with different levels of nonforage NDF.

\begin{tabular}{lccc}
\hline & \multicolumn{3}{c}{ Dietary treatments } \\
\cline { 2 - 4 } & $\mathrm{T} 1$ & $\mathrm{~T} 2$ & $\mathrm{~T} 3$ \\
\hline & 5.95 & 6.00 & 5.84 \\
Alfalfa & 22.26 & 22.52 & 10.76 \\
Pangola grass hay & 71.79 & 71.48 & 83.40 \\
Concentrate & & & \\
Concentrate & 61.53 & 29.52 & 46.90 \\
Ground corn & 34.35 & 22.31 & 19.64 \\
Soybean meal & - & 14.76 & 13.88 \\
Whole cottonseed & - & 23.36 & 12.63 \\
Wheat midds & - & 6.96 & 3.40 \\
Rice bran & 0.52 & 0.35 & 1.21 \\
Calcium PO & & 1.46 & 1.40 \\
Salt & 1.62 & - & 0.16 \\
Potassium Cl & 0.72 & 1.28 & 0.78 \\
Ground limestone & 1.26 & & \\
\hline
\end{tabular}

centration of the consumed ration was higher in $\mathrm{T} 3$ than in $\mathrm{T} 1$ and $\mathrm{T} 2$ (1.78 vs. 1.71 and 1.63); this finding was also influenced in large part by the fact that the forage to concentrate ratio was lowest in T3.

Observed differences in DM and organic matter (OM) consumption (Table 3) among treatments were not statistically significant $(P>0.05)$. Mean daily DM and OM intake and intake of each as a percentage of

TABLE 2. Chemical composition on a DM basis of alfalfa hay (AH), pangola grass hay (PGH) and concentrates for diets containing 25 and 19 (T1), 35 and 19 (T2), and 25 and $10 \%$ (T3) total NDF and NDF from forage, respectively.

\begin{tabular}{lrrrrr}
\hline & \multicolumn{4}{c}{ Dairy concentrates } & \\
\cline { 2 - 4 } & \multicolumn{1}{c}{ T1 } & \multicolumn{1}{c}{ T2 } & \multicolumn{1}{c}{ T3 } & AH & PGH \\
\hline Crude protein, \% & 23.07 & 23.17 & 15.90 & 19.40 & 6.00 \\
TDN, \% & 84.33 & 80.00 & 81.33 & 58.30 & 54.70 \\
NE $_{\mathrm{L}}$, Mcal/kg & 1.99 & 1.89 & 1.92 & 1.32 & 0.91 \\
$\mathrm{ADF}, \%$ & 4.30 & 10.40 & 7.20 & 33.60 & 42.70 \\
NDF, \% & 8.90 & 20.67 & 16.90 & 43.60 & 74.00 \\
Calcium, \% & 1.04 & 0.94 & 0.84 & 1.86 & 0.39 \\
Phosphorus, \% & 0.66 & 0.95 & 0.87 & 0.36 & 0.30 \\
Magnesium, \% & 0.22 & 0.38 & 0.28 & 0.20 & 0.35 \\
Potassium, \% & 0.85 & 1.10 & 0.67 & 2.47 & 1.50 \\
Sodium, \% & 0.79 & 0.64 & 0.69 & 0.09 & 0.32 \\
Chloride, \% & 1.29 & 0.79 & 1.12 & 0.90 & 0.96 \\
\hline
\end{tabular}


TABLE 3. Least square means for daily DM, OM, and NDF intake and intake as a percentage of body weight $(B W)$ of Holstein cows fed diets with different levels of nonforage fiber.

\begin{tabular}{lrrrrl}
\hline & \multicolumn{3}{c}{ Dietary treatments } & & \\
\cline { 2 - 3 } & $\mathrm{T} 1$ & $\mathrm{~T} 2$ & $\mathrm{~T} 3$ & Std. err. & $\mathrm{P}<$ \\
\hline Intake, kg/day & & & & & \\
$\quad$ DM & 18.05 & 18.30 & 18.58 & 0.41 & $\mathrm{NS}$ \\
OM & 16.98 & 17.14 & 17.47 & 0.38 & $\mathrm{NS}$ \\
NDF & 4.57 & 6.23 & 4.55 & 0.11 & 0.01 \\
Intake, \% of BW & & & & & \\
DM & 3.18 & 3.25 & 3.25 & 0.06 & $\mathrm{NS}$ \\
OM & 2.99 & 3.05 & 3.06 & 0.06 & $\mathrm{NS}$ \\
NDF & 0.80 & 1.10 & 0.79 & 0.02 & 0.01 \\
\hline
\end{tabular}

body weight (BW) were 18.4 and $17.3 \mathrm{~kg} / \mathrm{cow}$, and 3.23 and $3.03 \%$, respectively. Consumption of NDF was higher when cows received T2 rather than T1; this increase was influenced by the higher NDF concentration in the concentrate of T2. Similarly, intake of NDF as a percentage of BW was also greater when cows received T2. These results are as expected in view of the lack of a response in DM intake due to treatments. All of the dietary treatments resulted in NDF consumption that was below the $1.2 \% \mathrm{BW}$ level which was suggested as optimal to maximize DMI (Mertens, 1994).

Dietary treatments did not influence production of whole milk (Table 4). Mean daily production across treatments was $32.7 \mathrm{~kg} / \mathrm{cow}$, suggesting that all diets were nutritionally adequate to meet production potential under the conditions of the experiment. On the other hand, dietary treatments did influence $(\mathrm{P}<0.01)$ milk fat concentration. Reducing the NDFH from 19 to $10 \%$ (T1 vs. T3) resulted in a sharp decline in milk fat (3.07 vs. $2.59 \%$ ). For diets containing $19 \%$ NDFH an

TABLE 4. Least square means for milk, milk fat and protein production and milk composition of Holstein cows fed diets with different levels of nonforage fiber.

\begin{tabular}{|c|c|c|c|c|c|}
\hline & \multicolumn{3}{|c|}{ Dietary treatments } & \multirow[b]{2}{*}{ Std. Err. } & \multirow[b]{2}{*}{$\mathrm{P}<$} \\
\hline & $\mathrm{T} 1$ & $\mathrm{~T} 2$ & $\mathrm{~T} 3$ & & \\
\hline Milk yield, $\mathrm{kg} / \mathrm{d}$ & 32.30 & 33.00 & 32.80 & 0.69 & NS \\
\hline $3.25 \%-F C M, \mathrm{~kg} / \mathrm{d}$ & 31.40 & 31.90 & 29.40 & 0.88 & 0.14 \\
\hline MF yield, $\mathrm{kg} / \mathrm{d}$ & 1.00 & 1.00 & 0.87 & 0.04 & 0.05 \\
\hline MP yield, kg/d & 0.84 & 0.86 & 0.87 & 0.02 & NS \\
\hline $\mathrm{MF}, \%$ & 3.07 & 3.02 & 2.59 & 0.08 & 0.01 \\
\hline $\mathrm{MP}, \%$ & 2.63 & 2.64 & 2.67 & 0.04 & NS \\
\hline
\end{tabular}


increase in non-forage NDF from 6 to 16\% (T1 vs. T2) did not result in increased milk fat concentration. Differences observed in milk fat concentration resulted in a tendency for $3.25 \%$ fat-corrected milk (FCM) to be lower when cows consumed T3. Milk fat yield did decline significantly $(\mathrm{P}<0.05)$ when NDF from hay was reduced from 19 to $10 \%$. Dietary treatments did not influence milk protein concentration and milk protein yield; mean values were $2.65 \%$ and $0.86 \mathrm{~kg} / \mathrm{d}$.

The efficiency of DM and OM use for milk production was not influenced by dietary treatments (Table 5 ). On average, across dietary treatments, cows produced 1.79 and $1.90 \mathrm{~kg}$ of milk per $\mathrm{kg}$ of DM and OM consumed, respectively. On the other hand, the efficiency of use of $\mathrm{DM}$ and $\mathrm{OM}$ for FCM production was higher when cows consumed a diet with $19 \%$ NDF from hay (T1) than with a diet of only $10 \%$ NDF from forage (T3). Increasing the NDF in the concentrate from 6 to $16 \%$ did not influence the efficiency of DM or OM use for milk or FCM production (T1 vs. T2). Mean daily BW change during the trial was small, averaging $0.29 \mathrm{~kg} / \mathrm{cow}$, and differences among treatments were not significant. However, gains were highest when cows consumed T3.

The efficiency of nitrogen utilization, measured as nitrogen secreted in milk as a percentage of total nitrogen consumed in the ration, was higher when cows consumed T3 than for T1 and T2 (Table 5). The higher efficiency is mainly a function of the lower concentration of CP in the concentrate mix in T3 compared to that of the other two concentrates (15.04 vs. $19.06 \%)$; this, given the fact that milk protein concentration and milk production were similar among dietary treatments. Furthermore, when the nitrogen in BW change was considered, the advantage of T3 over the other treatments was larger ( 36.3 vs. $26.2 \%$ ). In both cases, the nitrogen efficiency was similar when cows consumed $\mathrm{T} 1$ and

TABLE 5. Least square means of efficiency of use of intakes of nitrogen (N), dry matter (DMI) and organic matter (OMI) use for milh (MY) and fat corrected milk (FCM) production of Holstein cows fed diets with different levels of nonforage fiber.

\begin{tabular}{lccccc}
\hline & \multicolumn{3}{c}{ Treatments } & & \\
\cline { 2 - 3 } & $\mathrm{T} 1$ & $\mathrm{~T} 2$ & $\mathrm{~T} 3$ & Std. err. & $\mathrm{P}<$ \\
\hline Efficiency, kg:kg & & & & & \\
$\quad$ MY/DMI & 1.79 & 1.80 & 1.77 & 0.04 & $\mathrm{NS}$ \\
FCM/DMI & 1.74 & 1.74 & 1.59 & 0.41 & 0.05 \\
MY/OM & 1.90 & 1.93 & 1.88 & 0.38 & $\mathrm{NS}$ \\
FCM/OM & 1.85 & 1.86 & 1.69 & 0.44 & 0.05 \\
Efficiency N, \% & & & & & \\
N milk/N feed & 24.50 & 24.90 & 31.20 & 0.69 & 0.01 \\
N (milk+BWG)/N feed & 25.10 & 27.40 & 36.30 & 1.41 & 0.01 \\
\hline
\end{tabular}


T2. These results suggest that with adequate concentration of dietary energy a ration with $15 \% \mathrm{CP}$ was sufficient to achieve the production levels observed in this trial. Thus, the additional $\mathrm{CP}$ in $\mathrm{T} 1$ and $\mathrm{T} 2$ did not contribute to an increase in protein yield or milk production.

The efficiency of milk production, measured as Mcal in milk divided by Mcal consumed from feed, was higher $(\mathrm{P}<0.01)$ when cows consumed T1 and T2 than for T3 (Table 6). On average, efficiency was 0.69 for T1 and T2 combined and only 0.60 when cows consumed T3. However, when the energy in BW change was considered in the production energy along with that in milk, the differences in efficiency among treatments were not significant. Apparently, the higher energy concentration and the insufficiency of effective fiber in T3 did not favor milk production, thus resulting in a lower portion of dietary energy going to milk.

A representation of the effect of experimental diets on ruminal $\mathrm{pH}$ of a Holstein cow in the period between the morning and afternoon feedings $(06: 30$ to $15: 30 \mathrm{~h}$ ) is presented in Figure 1. These data suggest a similar $\mathrm{pH}$ pattern when $\mathrm{T} 1$ and $\mathrm{T} 2$ rations were consumed. Therefore, no clear evidence was observed of an improvement increase in $\mathrm{pH}$ when nonforage fiber was used to raise the ration NDF concentration from 25 to $35 \%$. After the morning meal, when T1 and T2 were consumed, rumen $\mathrm{pH}$ declined rapidly during the first five hours after feeding to about 6.0 , and remained unchanged until 30 minutes prior to the next meal. When the diet with only $10 \%$ NDF from hay (T3) was consumed, the falling $\mathrm{pH}$ was faster and sharper than when diets with $19 \% \mathrm{NDFH}$ were consumed (T1 and T2). With T3 the $\mathrm{pH}$ dropped below 6.0 approximately 3.5 hours after feeding and remained under 6.0 for the remainder of the sampling period.

TABLE 6. Efficiency of conversion of feed $N E_{L}$ to milk production and body weight change (BWC) by cows consuming diets with different levels of nonforage fiber in the diet.

\begin{tabular}{lrrrrr}
\hline & \multicolumn{3}{c}{ Treatments } & & \\
\cline { 2 - 4 } & $\mathrm{T} 1$ & $\mathrm{~T} 2$ & $\mathrm{~T} 3$ & Std. err. & $\mathrm{P}<$ \\
\hline Source, Mcal/d & 30.89 & 30.01 & 33.90 & & \\
$\quad$ DMI & 20.78 & 20.99 & 19.54 & & - \\
$\quad$ Milk & 0.10 & 0.28 & 0.44 & & NS \\
Mean BWC, kg/d & 0.43 & 1.48 & 1.91 & & - \\
NEL in BWC, Mcal/d & & & & & \\
Estimated efficiency of & & & & & \\
production, Mcal/Mcal & 0.67 & 0.70 & 0.60 & 0.01 & 0.01 \\
$\quad$ Milk/DMI & 0.68 & 0.74 & 0.66 & 0.02 & 0.08 \\
$\quad$ (Milk+BWC)/DMI & & & & &
\end{tabular}




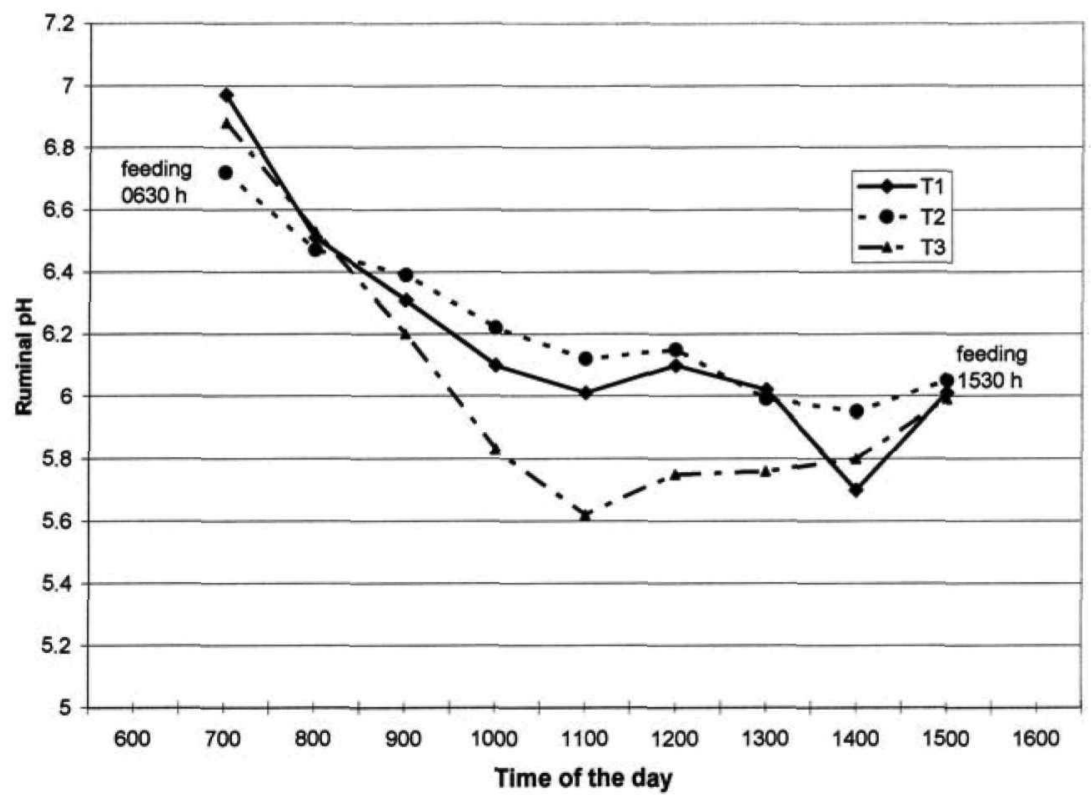

FIGURE 1. The effect of feeding diets with $19 \%$ NDF from hay and containing 25 (T1) or $35 \%$ (T2) total NDF and a diet with $10 \%$ NDF from hay and $25 \%$ total NDF (T3) on postprandial ruminal $\mathrm{pH}$ of a fistulated Holstein cow.

In this trial, non-forage fiber from a mixture of WCS, wheat midds, and rice bran was ineffective in preventing a depression of milk fat when replacing NDF from hay in a ration containing minimum levels of NDF. When the NDF from hay was reduced from 19 to $10 \%$ of the dietary DM, the concentration of milk fat was reduced by $15.6 \%$ in relative terms. When cows consumed T3 milk fat was significantly lower than the 3.0 to $3.25 \%$ range which is commonly observed for Holstein cows in early lactation consuming diets with minimum fiber concentration in the tropics (Ruiz et al., 2001). Reducing NDFH from 19 to $10 \%$ in $\mathrm{T} 3$ resulted in lower rumen $\mathrm{pH}$ relative to that of $\mathrm{T} 1$ and T2. The mixture of nonforage feeds used to raise dietary NDF concentration to $25 \%$ did not maintain milk fat concentration nor prevent a $\mathrm{pH}$ drop below 6.0 in rumen fluid. Thus, the reduction in milk fat appears to have been mediated through changes in ruminal acidity and the effect of $\mathrm{pH}$ on ruminal fermentation and absorption of metabolites.

These results are not in agreement with data from studies where either soybean hulls (Harminson et al., 1997) or distillers' grains (Staples et al., 1995) were used as nonforage fiber sources in the diet. 
The former authors found no decrease in milk fat concentration when soybean hulls were substituted for alfalfa hay in diets containing either 11 or $16 \%$ NDF from alfalfa, whereas Staples et al. found that feeding distillers' grains in place of corn in corn silage-based diets, marginal in NDF concentration (21 to $28 \%$ ), resulted in increases in milk fat concentration. Thus, the results of the present study support the hypothesis of Clark and Armentano (1997) that the potential of nonforage fiber to replace effective fiber in forage is compromised when a mixture of nonforage feeds, rather than each one individually, is included in the ration.

In conclusion, there was no evidence of an effective fiber value of wheat midds, whole cottonseed, and rice bran when fed as a mixture in the ration of Holstein cows in early lactation under the conditions of this study. The inclusion of this mixture did not prevent a sharp decline in milk fat concentration when the NDF from forage was lower than $19 \%$.

\section{LITERATURE CITED}

Clark, P. W. and L. E. Armentano, 1993. Effectiveness of neutral detergent fiber in whole cottonseed and dried distillers grains compared with alfalfa haylage. J. Dairy Sci. 76:2644.

Clark, P. W. and L. E. Armentano, 1997. Replacement of alfalfa neutral detergent fiber with a combination of nonforage fiber sources. J. Dairy Sci. 80:675.

Harmison, B., M. L. Eastridge and J. L. Firkins, 1997. Effect of percentage of neutral detergent fiber and source of starch on performance of lactating Jersey cows. J. Dairy Sci. 80:905.

Littell, R. C., R. J. Freund and P. C. Spector, 1991. SAS systems for linear models. Third Edition, SAS Institute, Inc., Cary, NC.

Mertens, D. R., 1994. Regulation of forage intake. pp. 450-493 In: Forage Quality, Evaluation and utilization, G. C. Fahey, Jr., M. Collins, D. R. Mertens and L. E. Moser (eds.), Am. Soc. Agron., Crop Sci. Soc. Am., and Soil Sci. Soc. Am., Madison, WI.

National Research Council, 1989. Nutrient requirements of dairy cattle. Sixth Revised Edition, National Academy Press, Washington, D.C.

Ruiz, T. M., M. López-Beníquez and R. Macchiavelli, 2001. Relación de la carga animal y el uso de alimento concentrado con el porcentaje de grasa láctea y la producción en los hatos lecheros de Puerto Rico. Agric. Exp. Stn., Univ. of P.R.-Mayagüez, Bull. 300.

Staples, C. R., B. S. Oldick, E. M. Hirchert and J. Velázquez, 1995. Identifying the effective fiber value of whiskey distillers dried grains with solubles in lactating dairy cow diets. In $6^{\text {th }}$ Annual Florida Ruminant Nutrition Symposium, Gainesville, FL.

Varga, G. A., H. M. Dann and V. A. Ishler, 1998. The use of fiber concentration for ration formulation. J. Dairy Sci. 81:3063. 